\title{
PEMANFAATAN ZEOLIT ALAM SEBAGAI MEDIA PENDUKUNG AMOBILISASI ENZIM $\alpha$-AMILASE
}

\author{
Upita Septiani dan Agrina Lisma \\ Jurusan Kimia Fakultas Matematika dan Ilmu Pengetahuan Alam, \\ Universitas Andalas
}

\begin{abstract}
The utilization of natural zeolite as supporting media of $\alpha$-amylase enzyme has been done. Natural zeolite which is activated with $3 \mathrm{M} \mathrm{HCl}$ can remove impurities in the surface natural zeolite, uncover and widen the pores of the zeolite and activate functional groups to interact with $\alpha$ amylase enzyme in the process of immobilization enzyme process. The mass of activated natural zeolite which is used as a material immobilized to get the optimal activity of $\alpha$-amylase enzyme was 0.3 gram. Based on the measurement result of optimization of $\alpha$-amylase enzyme were obtained optimum temperature of $35^{\circ} \mathrm{C}, \mathrm{pH} 5.6$ and incubation time of 35 minutes with 0.04845 units $/ \mathrm{mL}$ of the unit activity. And for $\alpha$-amylase immobilized enzyme will be stable at the optimum temperature of $50^{\circ} \mathrm{C}, \mathrm{pH} 5.6$ and incubation time of 45 minutes with 0.030 units $/ \mathrm{mL}$ of the unit activity. SEM-EDX pattern shows the differences in surface morphology between natural zeolite and activated natural zeolites which contain $\alpha$-amylase enzyme. A mobilization technique can increase the stability utilized in a $\alpha$-amylase enzyme.
\end{abstract}

Keywords : Zeolite, amobilization, $\alpha$-amylase enzyme

\section{PENDAHULUAN}

Mineral zeolit telah dikenal sejak zaman romawi kuno, tetapi belum ditingkatkan secara optimal. Upaya-upaya penelitian dan pengembangan berwawasan lingkungan terhadap sumber daya mineral tersebut perlu terus dilakukan sehingga dapat memberikan hasil yang nyata. Sifat yang dimiliki oleh zeolit memungkinkan untuk dimodifikasi menjadi katalis, adsorben, dan sebagai matrik pengamobil. Zeolit merupakan mineral yang cukup berlimpah di Indonesia, karena wilayah Indonesia sebagian besar terdiri dari batuan gunung api atau rempah-rempah gunung api yang merupakan sumber mineral zeolit $^{[1]}$.

Zeolit alam pada umumnya memiliki ukuran pori yang tidak seragam, aktifitas katalitik rendah dan banyak mengandung pengotor. Oleh karena itu, perlu diaktivasi terlebih dahulu sebelum digunakan. Aktivasi zeolit dapat dilakukan dengan dua cara, yaitu cara kimia dan cara fisika. Aktivasi dengan cara fisika dilakukan dengan pemanasan sedangkan dengan cara kimia dilakukan dengan pemberian asam atau basa ${ }^{[2]}$.

Zeolit terdiri dari kristal aluminosilikat terhidrasi yang mengandung kation alkali atau alkali tanah dalam kerangka tiga dimensinya. Kation tersebut dapat digantikan oleh kation-kation lain atau molekul lain tanpa merusak struktur zeolit dan dapat menyerap air secara reversible. Kation atau molekul lain tersebut dapat bergerak bebas yang memungkinkan zeolit dapat digunakan sebagai matrik pendukung untuk mengamobilisasi enzim ${ }^{[2,3]}$.

Penggunaan enzim amilase dalam industri akhir-akhir ini terus meningkat. Enzim ini menyumbang sekitar $30 \%$ dari total produksi enzim dunia dan mempunyai aplikasi yang luas di dalam industri. Beberapa industri yang menggunakan amilase adalah industri pengolah pati, makanan, pemeraman, deterjen, tekstil, dan kertas. Dilaporkan, enzim amilase yang digunakan dalam industri tekstil di Bandung, Jawa Barat jumlahnya tidak kurang dari 4 ton per bulan 
atau sekitar 2-3 juta dolar Amerika setiap bulannya ${ }^{[3,4]}$.

Enzim mempunyai efisiensi kerja dan spesifitas yang tinggi, aktif pada suhu ruang dan $\mathrm{pH}$ yang mendekati normal serta memberikan peningkatan laju reaksi yang luar biasa dibandingkan dengan katalis lain. Penggunaan enzim juga tidak perlu mempertimbangkan faktor keamanan karena enzim itu sendiri adalah senyawa alami yang dapat diuraikan dan akan memberikan asam amino bila dihidrolisis ${ }^{[5]}$.

Secara umum enzim larut dalam air sehingga banyak enzim yang tidak ekonomis untuk digunakan pada pengoperasian dalam skala besar karena hanya dapat digunakan satu kali proses dengan biaya yang cukup mahal. Untuk mengatasi masalah ini dapat dilakukan dengan menjebak enzim dalam bahan-bahan yang tidak larut dalam air, dimana bahanbahan tersebut dapat dipisahkan dengan mudah. Hal ini memungkinkan penggunaan kembali bahan-bahan tak larut yang mengandung enzim tersebut. Proses ini disebut dengan amobilisasi enzim ${ }^{[6]}$.

Pada penelitian ini digunakan zeolit sebagai senyawa pengamobilisasi enzim $\alpha$-amilase dimana sebelumnya dilakukan pengaktifan zeolit alam dengan $\mathrm{HCl}$. Kemudian dipelajari masa optimum zeolit alam aktivasi agar dapat digunakan untuk mengamobilisasi enzim sehingga menghasilkan kinerja enzim yang maksimal.

\section{METODOLOGI PENELITIAN}

\begin{abstract}
Alat dan Bahan
Peralatan yang digunakan dlam penelitian ini adalah magnetic stirrer (Agimatic REV-E), oven, sentrifuge, $\mathrm{pH}$ meter (Metro-HOME), incubator (Gallenkamp), spektrofotometer UV/VIS (Spektronik 20D), neraca listrik (KERN-ew), desikator, kertas saring W-41, peralatan gelas.
\end{abstract}

Bahan-bahan dan reagen kimia yang digunakan adalah zeolit alam dari Gunung Kidul, enzim $\alpha$-amilase dari Balai Besar Litbang Pascapanen, amilum, maltosa, asam sitrat, natrium sitrat (Wako Pure Chemical Industries), asam molibdat, fosfomolibdat, natrium karbonat, kalium natrium tartarat, natrium bikarbonat, natrium sulfat anhidrat, tembaga sulfat penta hidrat, natrium hidroksida, natrium tungstat, dan asam pospat (Merck).

\section{Pembuatan Reagen}

Pembuatan Reagen Nelson, Reagen Fosfomolibdat, Larutan Substrat Amilum untuk uji aktifitas enzim sesuai dengan standar ${ }^{[7]}$.

\section{Prosedur Kerja}

\section{Aktivasi Zeolit Alam}

Aktivasi zeolit alam dilakukan dengan cara mencampurkan $30 \mathrm{~g}$ zeolit alam dan $100 \mathrm{~mL}$ $\mathrm{HCl} 3 \mathrm{M}$. Campuran dipanaskan sambil diaduk pada suhu $90{ }^{\circ} \mathrm{C}$ selama 2 jam, kemudian didinginkan, disaring dan dicuci dengan aquades sampai zeolit tidak berwarna kekuningan lagi. Lalu dikeringkan dalam oven pada suhu $105{ }^{\circ} \mathrm{C}$ selama 5 jam, dan disimpan dalam desikator.

\section{Penentuan Massa Optimum Zeolit Aktivasi untuk Amobilisasi Enzim $\alpha$ - Amilase}

Sebanyak $1 \mathrm{~mL}$ buffer sitrat $\mathrm{pH}$ optimum diaduk dengan variasi massa $0,1-1 \mathrm{~g}$ zeolit alam aktivasi dan didiamkan selama 30 menit. Kemudian ditambahkan $1 \mathrm{~mL}$ enzim $\alpha$ amilase ke dalam masing-masing zeolit. Campuran diaduk dan didiamkan selama 60 menit. Enzim yang telah diamobil ditambahkan dengan substrat amilum 2\% dan diinkubasi selama waktu 35 menit pada suhu $35{ }^{\circ} \mathrm{C}$. Selanjutnya enzim yang telah diamobilisasi dipisahkan dari produk dengan melakukan sentrifus selama 5 menit dan filtratnya ditambahkan dengan $1 \mathrm{~mL}$ reagen Nelson dan dipanaskan selama 20 menit, kemudian dinginkan hingga suhu $26{ }^{\circ} \mathrm{C}$. Setelah itu tambahkan $1 \mathrm{~mL}$ reagen Fosfomolibdat dan dikocok hingga sempurna. Lalu tambahkan $7 \mathrm{~mL}$ aquades dan diamkan selama 30 menit. Absorban larutan diukur pada panjang gelombang $640 \mathrm{~nm}$. Massa zeolit yang menunjukkan enzim yang telah 
diamobil dengan aktivitas optimum akan digunakan untuk amobilisasi selanjutnya.

\section{Amobilisasi Enzim $\alpha$-Amilase}

Pada $1 \mathrm{~mL}$ enzim $\alpha$-amilase ditambahkan 0,3 $\mathrm{g}$ zeolit alam aktivasi yang telah disesuaikan pH-nya dengan enzim $\alpha$-amilase. Campuran diamkan pada suhu kamar selama 1 jam dengan sesekali pengadukan. Kemudian campuran disentrifuse selama 5 menit. Endapan yang diperoleh merupakan enzim amobil (enzim yang telah diamobilisasi).

\section{Penentuan pH Optimum Enzim $\alpha$-amilase Sebelum dan Setelah Amobilisasi}

Pada penentuan $\mathrm{pH}$ Optimum ini, prosedur kerjanya sama dengan penentuan massa optimum zeolit aktivasi untuk amobilisasi Enzim $\alpha$-amilase tetapi pHnya divariasikan yaitu dari $\mathrm{pH} 5-6,4$.

\section{Penentuan Suhu Optimum Enzim a- amilase Sebelum dan Setelah Amobilisasi}

Pada penentuan Suhu Optimum ini, prosedur kerjanya sama dengan penentuan massa optimum zeolit aktivasi untuk amobilisasi Enzim $\alpha$-amilase tetapi suhu inkubasi divariasikan yaitu dari $30-55^{\circ} \mathrm{C}$.

\section{Penentuan Waktu Inkubasi Optimum Enzim $\alpha$-amilase Sebelum dan Setelah Amobilisasi}

Pada penentuan Waktu Inkubasi Optimum ini, prosedur kerjanya sama dengan penentuan massa optimum zeolit aktivasi untuk amobilisasi enzim $\alpha$-amilase tetapi waktu inkubasi divariasikan yaitu dari $30-55$ menit.

\section{Penentuan Aktifitas Enzim $\alpha$-Amilase Sebelum dan Setelah Amobilisasi Pada Kondisi Optimum}

Prosedur kerjanya sama dengan penentuan massa optimum zeolit aktivasi untuk amobilisasi enzim $\alpha$-amilase tetapi semua dilakukan kondisi optimum.

\section{Penentuan Aktivitas Enzim $\alpha$-Amilase Amobilisasi Setelah Pemakaian Berulang}

Pada enzim yang telah diamobil penambahan substrat amilum $2 \%$ diulangi sampai beberapa kali untuk mengetahui kemampuan kontinuitas enzim dalam menguraikan substrat.

\section{HASIL DAN DISKUSI}

\section{Aktivasi zeolit alam}

Teknik amobilisasi enzim adalah teknik pengikatan/penjebakan enzim pada bahanbahan yang tidak larut dalam air, dimana bahan-bahan tersebut dapat dipisahkan dari produk dengan mudah sehingga bahan-bahan tak larut yang mengandung enzim tersebut digunakan kembali. Pada penelitian ini bahan yang digunakan sebagai pengamobil adalah zeolit alam. Pada umumnya zeolit alam memiliki ukuran pori yang tidak seragam, aktifitas katalitiknya rendah dan mengandung banyak pengotor. Oleh karena itu perlu diaktivasi terlebih dahulu sebelum dapat digunakan.

Zeolit alam sebagai material awal diaktivasi dengan perlakuan asam. Dalam penelitian ini asam yang digunakan adalah asam klorida karena asam klorida dikenal sebagai asam yang mampu melarutkan senyawa anorganik. Menurut M.Sutarti dan Minta Rachmawati (1994) aktivasi zeolit dengan $\mathrm{HCl}$ dapat membersihkan pengotor-pengotor sehingga memperbesar permukaan pori-pori zeolit alam dan mengatur kembali posisi atom yang dapat dipertukarkan. Perlakuan asam pada padatan zeolit menyebabkan zeolit lebih bersih dari pengotor sehingga pori-pori zeolit lebih terbuka dan dapat digunakan untuk halhal lain yang lebih bermanfaat ${ }^{[2.3]}$.

Konsentrasi asam klorida $(\mathrm{HCl})$ yang digunakan adalah sebesar $3 \mathrm{M}$. Berdasarkan penelitian yang dilakukan oleh D. Srihapsari (2006), aktivasi zeolit dengan $\mathrm{HCl}$ konsentrasi 3M lebih optimum untuk mengaktifkan pori-pori permukaan zeolit jika dibandingkan dengan konsentrasi $\mathrm{HCl} 1 \mathrm{M}$ dan 2M. Pada zeolit yang belum diaktivasi larutan asam berwarna bening sedangkan setelah diaktivasi, larutan asam berubah menjadi bewarna kuning. Warna larutan 
asam yang berwarna kuning menandakan bahwa pengotor-pengotor yang berada dalam zeolit alam telah terekstrak ke dalam asam ketika dipanaskan. Menurut R. Bakri, dkk (2008) proses pengaktifan dengan asam akan melarutkan pengotor-pengotor dan yang terdapat dalam zeolit yang ditandai dengan larutan berwarna kuning kehijauan yang mengandung senyawa dari logam-logam pengotor yang terdapat dalam zeolit. Sedangkan jika proses pengaktivasian hanya dilakukan dengan pemanasan saja maka hanya akan menghasilkan peristiwa dehidroksilasi (pelepasan air) dari zeolit ${ }^{[18]}$.

Penentuan pH Optimum Sebelum dan Setelah Amobilisasi Enzim o-Amilase

Tujuan menentukan $\mathrm{pH}$ optimum adalah untuk mengetahui kondisi lingkungan enzim $\alpha$-amilase dalam berinteraksi dengan substrat amilum untuk mendapatkan jumlah produk maltosa yang maksimum. Kondisi $\mathrm{pH}$ yang optimum akan mendukung enzim dalam melakukan katalisis suatu reaksi dengan baik. Berdasarkan penelitian K. Vidilaseris (2007) enzim $\alpha$-amilase memiliki aktifitas optimum pada range $\mathrm{pH} 5,0-8,0^{[19]}$.

Pada Gambar 1 dapat dilihat bahwa aktivitas enzim $\alpha$-amilase baik yang sebelum maupun yang setelah diamobil makin meningkat seiring dengan bertambahnya $\mathrm{pH}$ karena enzim $\alpha$-amilase dibawah $\mathrm{pH}$ optimumnya belum beraktifitas dengan sempurna, sehingga aktifitasnya akan terus naik sampai pada titik pH optimumnya yaitu 5,6 . Namun setelah melewati batas $\mathrm{pH}$ optimum aktifitas enzim $\alpha$-amilase baik yang sebelum diamobil maupun yang sesudah diamobil akan mengalami penurunan. Menurut A. Budiman dan Sigit Setyawan penurunan aktifitas enzim setelah $\mathrm{pH}$ optimum terjadi karena enzim akan mengalami denaturasi akibat ketidakstabilan katalisis yang menyebabkan fungsi dan aktifitas dari enzim tersebut berkurang ${ }^{[9]}$.

Gambar 1 juga menunjukkan $\mathrm{pH}$ optimum enzim $\alpha$-amilase sebelum diamobil dan yang telah diamobilisasi tidak mengalami perubahan. Karena proses amobilisasi enzim pada zeolit alam yang telah diaktivasi tidak mempengaruhi perubahan $\mathrm{pH}$ awal dari enzim tersebut. Hal ini menunjukkan bahwa kestabilan $\mathrm{pH}$ enzim $\alpha$-amilase tetap terjaga setelah diamobilisasi pada zeolit alam yang telah diaktivasi.

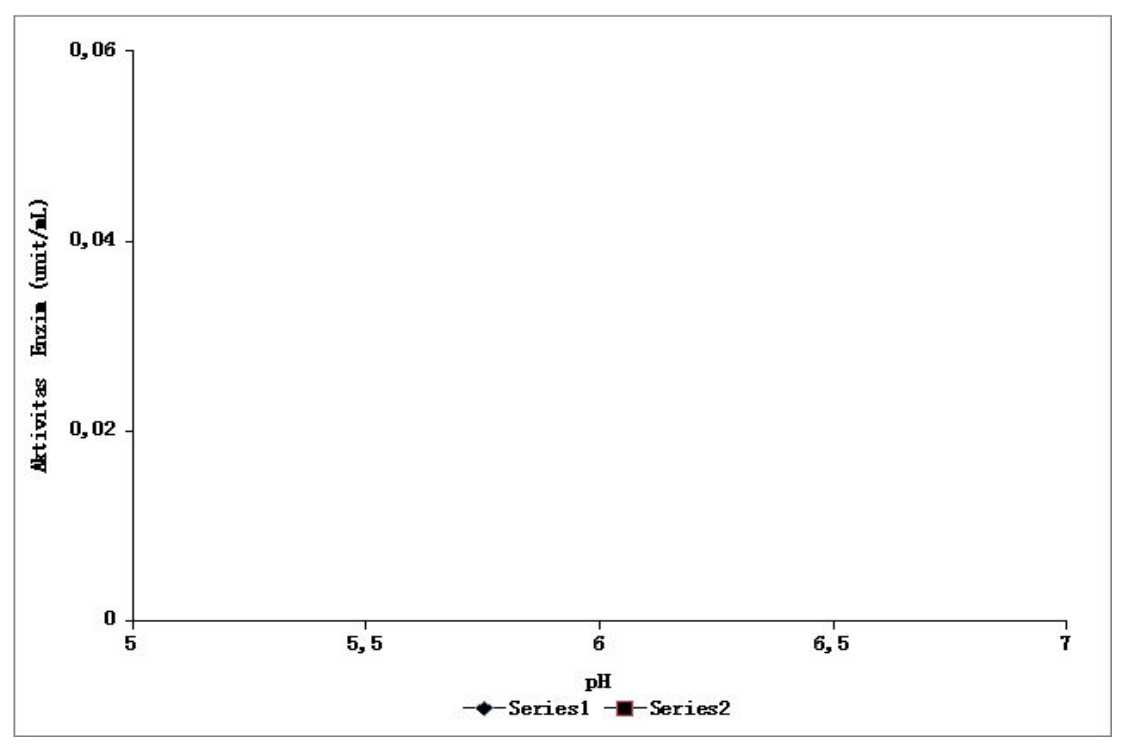

Gambar 1. Variasi pH terhadap enzim $\alpha$-amilase sebelum amobilisasi $(\bullet)$ dan setelah amobilisasi ( $\square$ 


\section{Penentuan Waktu Inkubasi Optimum}

Penentuan waktu inkubasi optimum enzim $\alpha$ amilase sebelum diamobilisasi dengan enzim $\alpha$-amilase yang telah diamobilisasi dapat dilihat pada Gambar 2. Waktu inkubasi merupakan waktu yang diperlukan enzim $\alpha$ amilase untuk berinteraksi dengan substrat amilum sehingga menghasilkan produk maltosa, dimana pada waktu inkubasi optimumnya substrat amilum menghasilkan produk maltosa dalam jumlah maksimum. Berdasarkan hasil penelitian, aktivitas enzim $\alpha$-amilase sebelum dan sesudah diamobil makin meningkat seiring dengan bertambahnya waktu inkubasi sampai pada waktu inkubasi optimumnya, yaitu 35 menit pada enzim $\alpha$-amilase yang belum diamobilisasi dan 45 menit pada enzim $\alpha$ amilase yang telah diamobilisasi. Karena enzim $\alpha$-amilase dibawah waktu inkubasi optimumnya belum beraktifitas dengan sempurna, sehingga aktifitasnya akan terus naik sampai pada waktu inkubasi optimumnya. Namun setelah melewati dari waktu optimum tersebut aktivitas enzim $\alpha$ amilase baik yang belum diamobilisasi maupun yang telah diamobilisasi sama-sama mengalami penurunan. Menurut A. Laila dan John Hendri (2008) turunnya aktivitas enzim setelah waktu inkubasi optimum disebabkan oleh perubakan kondisi reaksi yaitu perubahan $\mathrm{pH}$ yang disebabkan bertambahnya produk pada akhir reaksi ${ }^{[6]}$.

Waktu inkubasi optimum enzim $\alpha$-amilase yang belum diamobilisasi adalah 35 menit sedangkan pada enzim $\alpha$-amilase yang telah diamobilisasi adalah 45 menit. Perbedaan waktu optimum ini disebabkan karena interaksi enzim $\alpha$-amilase yang belum diamobil dapat langsung terjadi dengan substrat amilum. Sedangkan pada enzyme $\alpha$ amilase yang telah diamobilisasi interaksi substrat amilum dengan enzim $\alpha$-amilase mempunyai halangan ruang pada zeolit sehingga membutuhkan waktu lebih lama untuk melakukan katalisis.

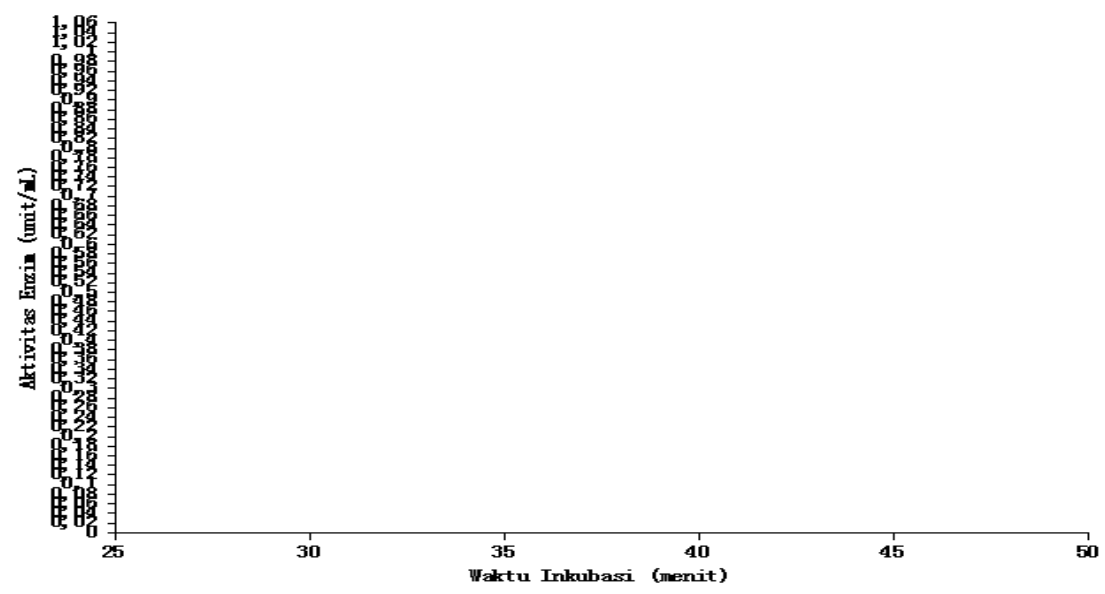

Gambar 2. Variasi waktu inkubasi terhadap aktifitas enzim $\alpha$-amilase sebelum amobilisasi dan setelah amobilisasi (ם)

\section{Penentuan Suhu Optimum}

Pengaruh suhu terhadap aktivitas enzim $\alpha$ amilase sebelum dan sesudah amobilisasi dapat dilihat pada Gambar 3. Pada Gambar 3 dapat dilihat bahwa aktivitas enzim $\alpha$-amilase baik yang sebelum maupun yang setelah diamobil makin meningkat seiring dengan bertambahnya suhu karena aktifitas enzim $\alpha$ amilase dibawah suhu optimumnya belum beraktifitas dengan sempurna, sehingga aktifitasnya akan terus naik sampai pada titik suhu optimumnya yaitu $35^{\circ} \mathrm{C}$ untuk enzim $\alpha$ amilase bebas dan $50{ }^{\circ} \mathrm{C}$ untuk enzim $\alpha$ amilase amobil. Namun setelah melewati batas suhu optimum aktifitas enzim $\alpha$ amilase baik yang sebelum diamobil maupun yang sesudah diamobil akan mengalami penurunan karena enzim mengalami denaturasi akibat ketidakstabilan katalisis yang menyebabkan fungsi dan aktifitas dari enzim tersebut berkurang ${ }^{[9]}$. 
Terdapat perbedaan suhu optimum antara enzim $\alpha$-amilase sebelum amobilisasi dengan enzim $\alpha$-amilase setelah diamobilisasi, dimana aktivitas optimum enzim $\alpha$-amilase bebas terjadi pada suhu $35{ }^{\circ} \mathrm{C}$ sedangkan pada enzim $\alpha$-amilase yang telah diamobilisasi mengalami aktifitas optimum pada suhu $50^{\circ} \mathrm{C}$. Menurut R. Trifani (2002) enzim yang terjebak dalam zeolit akan lebih terlindungi dari suhu yang tinggi sehingga kecendrungan mengalami denaturasi dan kerusakan pada enzim dan substrat dapat dikurangi. Dan inilah yang menyebabkan enzim $\alpha$-amilase amobil lebih stabil terhadap panas daripada $\alpha$-amilase yang belum diamobil ${ }^{[5]}$.

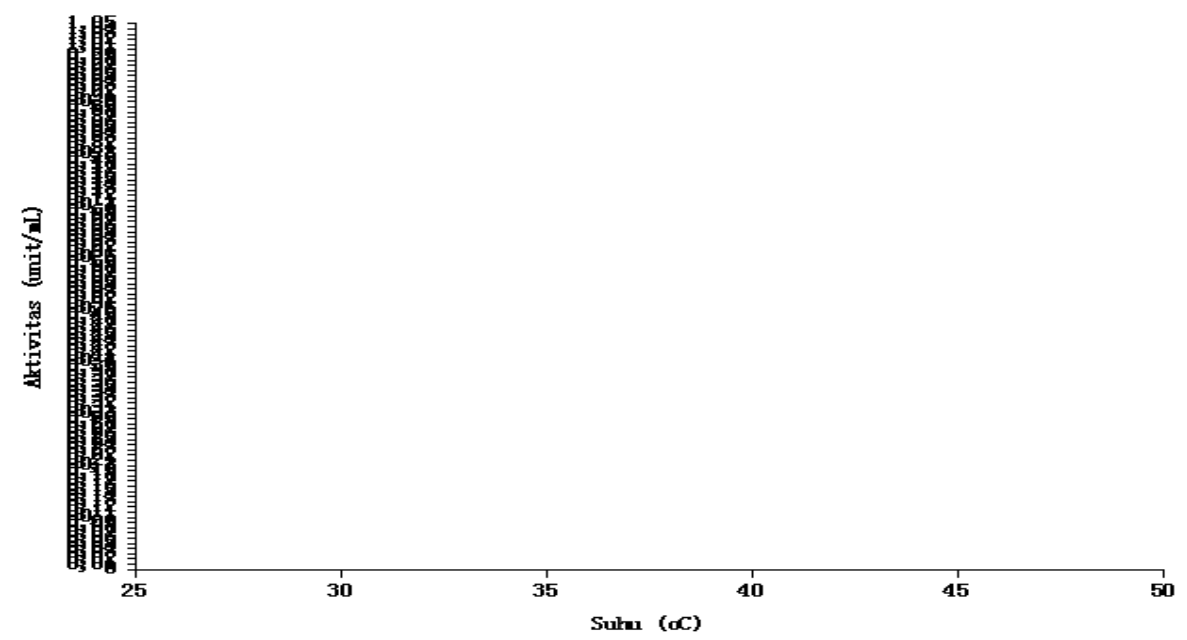

Gambar 3. Variasi suhu terhadap aktifitas enzim $\alpha$-amilase sebelum amobilisasi ( ) dan setelah amobilisasi

\section{Penentuan Massa Zeolit Aktivasi Optimum}

Amobilisasi enzim $\alpha$-amilase ini adalah metoda secara fisika pada permukaan bahan yang tidak larut dalam air. Metoda ini juga merupakan metoda yang sederhana dan hemat biaya dari metoda lainnya. Bahan yang tidak larut dalam air ini juga dapat meminimalisir bercampurnya reaksi dan dapat digunakan sebagai bahan pendukung untuk adsorpsi fisik yang tahan lama serta dapat digunakan kembali. Cara ini dilakukan karena tidak merusak enzim karena struktur alami enzim tidak mengalami gangguan. Selain itu dengan menggunakan teknik ini enzim dapat digunakan secara berulang dan penghentian proses amobilisasi juga cepat ${ }^{[8]}$.
Gambar 4 memperlihatkan massa zeolit yang tepat untuk digunakan dalam amobilisasi enzim $\alpha$-amilase adalah $0,3 \mathrm{~g}$, dimana interaksi fisik yang terjadi diantara enzim dan zeolit paling kuat. Semakin banyak massa zeolit yang digunakan maka interaksi fisik zeolit alam terhadap enzim makin kurang. Hal ini ditunjukkan oleh makin menurunnya aktivitas yang diberikan oleh enzim. Penurunan aktifitas pada saat amobilisasi, diakibatkan karena zeolit yang terlampau banyak mengakibatkan sulitnya interaksi hidropobik enzim untuk bercampur dengan zeolit yang disebabkan karena interaksi yang terjadi antara enzim dengan zeolit ini tidak kuat karena hanya mempunyai interaksi yang lemah yaitu interaksi Van der Waal dan interaksi hidropobik. 


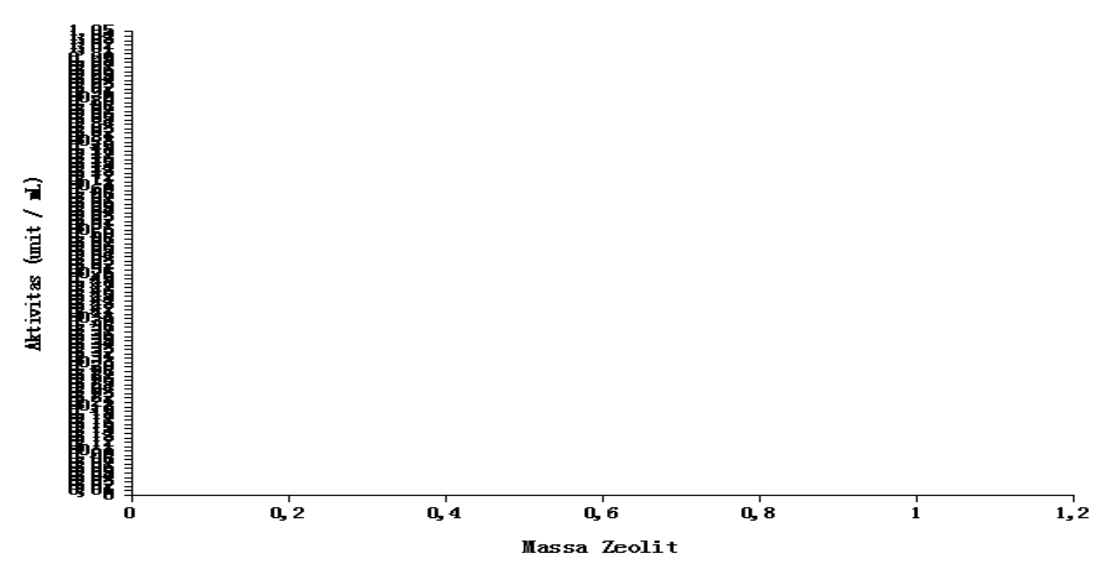

Gambar 4. Variasi massa zeolit aktivasi terhadap aktivitas enzim $\alpha$-amilase

\section{Pengulangan Pemakaian Enzim $\alpha$-Amilase Setelah Amobilisasi}

Seperti yang telah dikatakan sebelumnya bahwa keunggulan dari amobilisasi enzim adalah dapat digunakan berulang kali, tetapi tentu saja dengan aktifitas yang makin menurun. Hasil pemakaian enzim $\alpha$-amilase yang telah diamobilisasi secara berulang kali dapat dilihat pada Gambar 5. Dari Gambar 5 dapat dilihat bahwa aktifitas enzim $\alpha$-amilase yang telah diamobilisasi dapat digunakan sampai 3 kali pemakaian. Penurunan aktifitas ini disebabkan oleh faktor tidak kuatnya ikatan antara enzim dengan bahan pendukung sehingga terjadi pelepasan enzim yang berada dalam zeolit selama pemakaian.

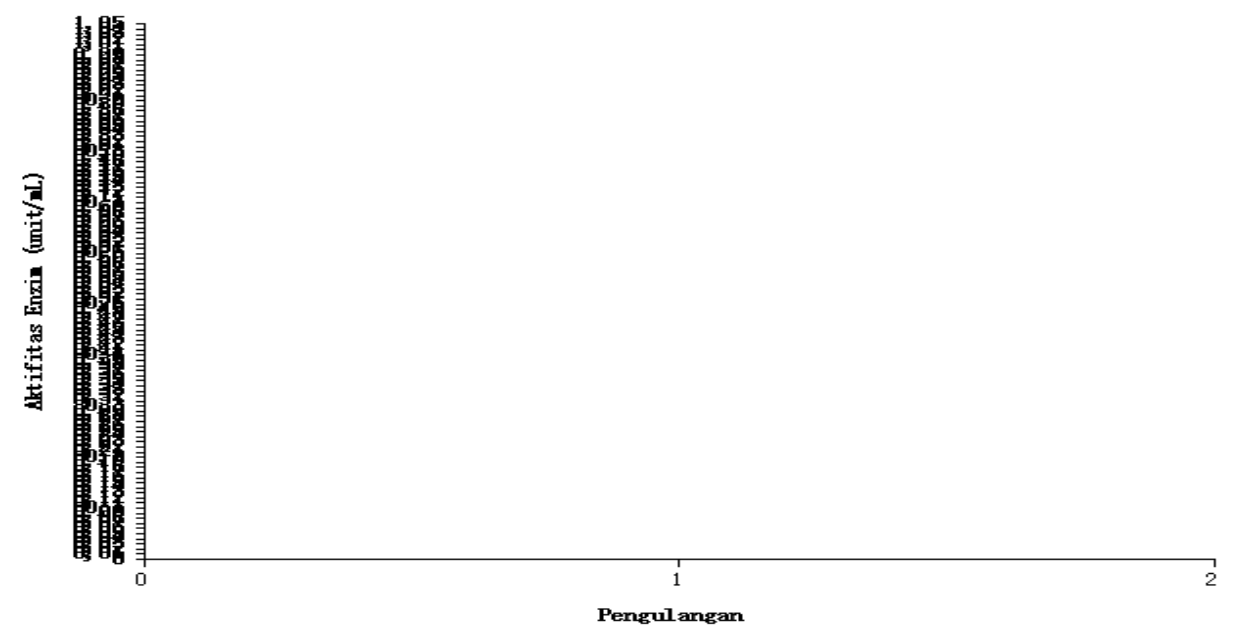

Gambar 5. Aktivitas enzim $\alpha$-amilase amobilisasi setelah pemakaian berulang

\section{Karakterisasi dengan Scanning Electron Microscopy-Energy Dispersive X-Rays Spectroscopy (SEM-EDX)}

Dari pola SEM pada Gambar 6 dapat dilihat bahwa terjadi perbedaan morfologi permukaan antara zeolit aktivasi dengan zeolit aktivasi yang menjebak enzim. Gambar 6a. menunjukkan permukaan zeolit aktivasi yang lebih kasar dan tidak beraturan, dibandingkan dengan zeolit alam yang mengandung enzim. Pada Gambar $6 b$ terlihat enzim $\alpha$-amilase telah menyelimuti permukaan dari zeolit tersebut sehingga dapat disimpulkan bahwa enzim $\alpha$-amilase telah teramobil dalam zeolit alam teraktivasi. 


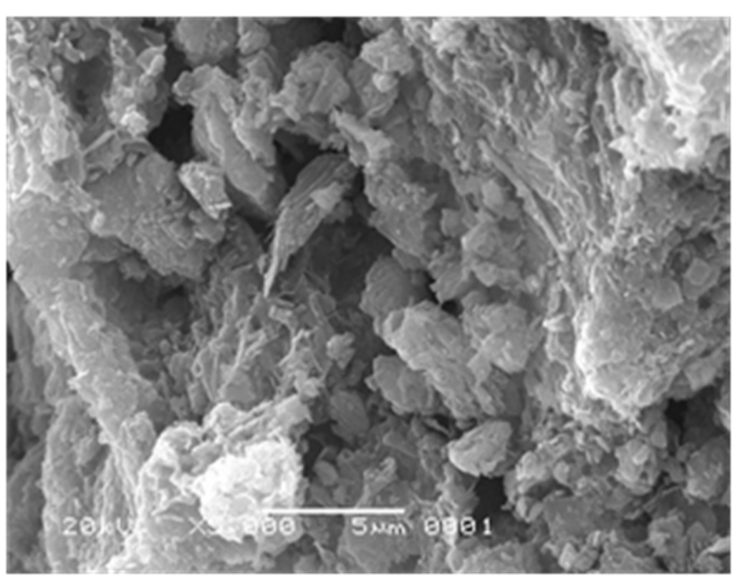

a

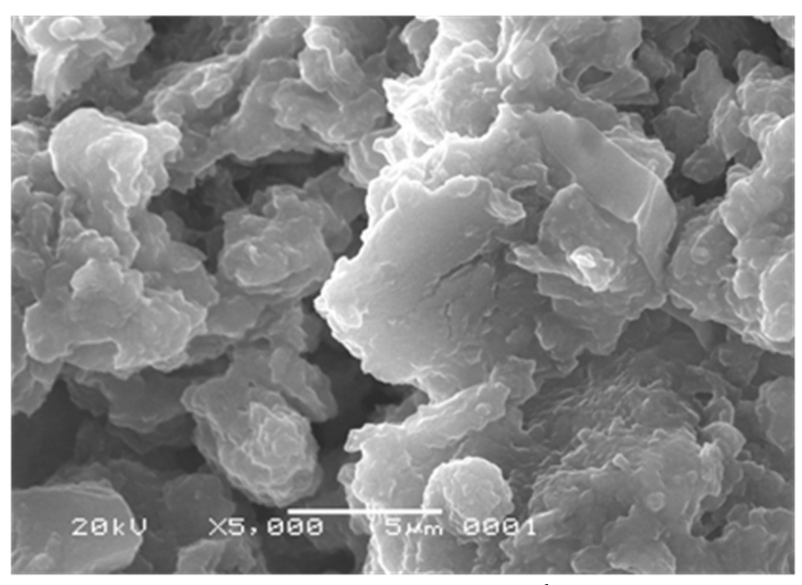

b

Gambar. 6. Pola SEM dengan pembesaran 5000 kali dari a. Zeolit alam yang telah diaktivasi, b. Zeolit enzim

Pola EDX dari zeolit alam aktivasi dan zeolit teramobil enzim amilase dapat dilihat pada Gambar 7. Pada zeolit alam aktivasi yang tidak mengandung enzim hanya terdapat senyawa-senyawa pembentuk batuan zeolit ini saja seperti $\mathrm{SiO}_{2}, \mathrm{Al}_{2} \mathrm{O}_{3}$ dan oksida-oksida lainya seperti $\mathrm{K}_{2} \mathrm{O}$ dan $\mathrm{CaO}$. Sedangkan pada zeolit alam yang mengandung enzim dapat kita lihat bahwa adanya penambahan atom $\mathrm{C}$ (pada puncak pertama setelah $0,00 \mathrm{eV}$ ) dan gugus fungsi lain dari asam-asam amino enzim $\alpha$-amilase telah mengisi sebahagian dari volume zeolit selain dari senyawasenyawa pembentuk batuan zeolit tersebut. Hal ini membuktikan bahwa enzim $\alpha$-amilase telah berada di permukaan zeolit alam yang telah diaktivasi.

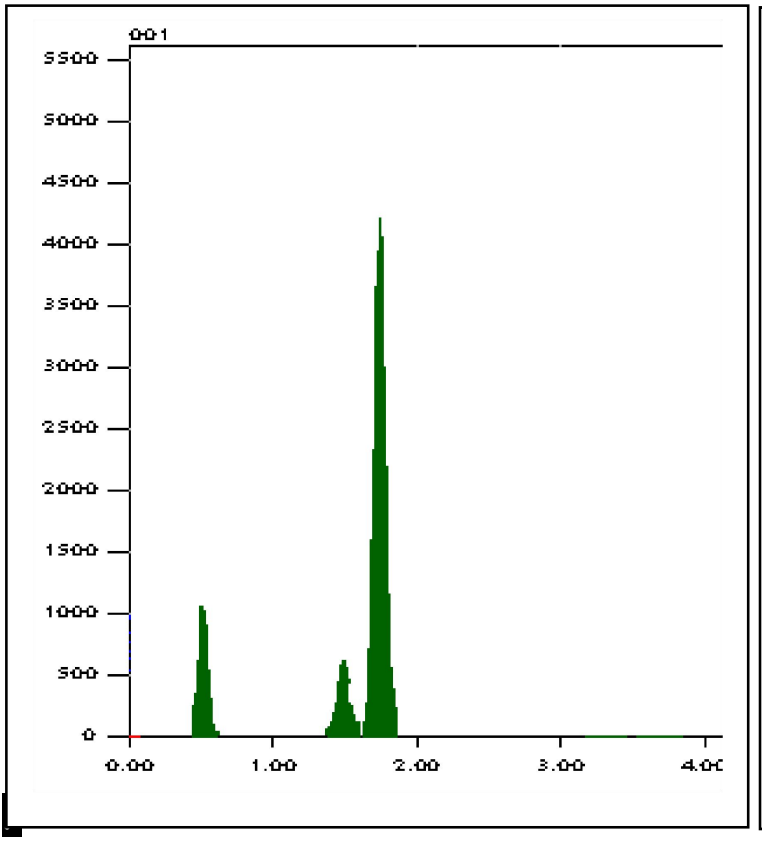

a

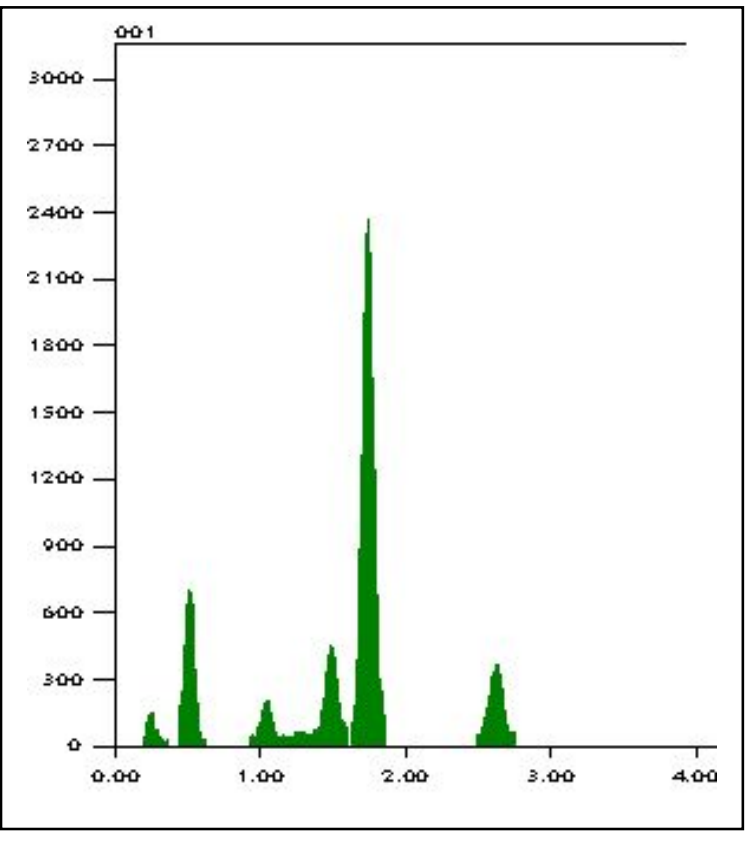

b

Gambar 7. Pola EDX dari a. Zeolit alam yang telah diaktivasi, b. Zeolit enzim. 


\section{KESIMPULAN}

Dari hasil penelitian yang telah dilakukan maka dapat disimpulkan beberapa hal, yaitu :

1 Zeolit alam teraktivasi dari Gunung Kidul dapat digunakan sebagai bahan pendukung untuk amobilisasi enzim $\alpha$ amilase, berdasarkan hasil analisis SEMEDX.

2 Masa zeolit alam teraktivasi yang dibutuhkan untuk mendapatkan aktivitas optimum dari enzim $\alpha$-amilase amobil adalah $0,3 \mathrm{~g}$.

3 Terdapat perbedaan kondisi optimal antara enzim $\alpha$-amilase bebas dengan enzim $\alpha$-amilase amobil, kondisi masingmasingnya adalah suhu $35^{\circ} \mathrm{C}, \mathrm{pH} 5,6$, waktu inkubasi 35 menit dengan aktivitas unit sebesar 0,04845 unit $/ \mathrm{mL}$. Sedangkan untuk enzim $\alpha$-amilase amobil adalah suhu $50{ }^{\circ} \mathrm{C}, \mathrm{pH}$ 5,6 dan waktu inkubasi 45 menit dengan aktivitas unit sebesar 0,030036 unit $/ \mathrm{mL}$.

4 Enzim $\alpha$-amilase yang telah diamobilisasi dapat digunakan sebanyak 3 kali pengulangan dengan penurunan aktivitas sebesar $30-70 \%$.

\section{DAFTAR PUSTAKA}

1. Setiadi dan A. Pertiwi, Preparasi dan karakterisasi zeolit alam untuk konversi senyawa ABE menjadi hidrokarbon. Universitas Indonesia. Jakarta, (2007).

2. M. Sutarti dan M. Rachmawati, Zeolit : tinjauan literature, Jakarta, (1994).

3. Amalia, Amobilisasi enzim papain dari getah papaya pada zeolit alam yang telah diaktivasi. Universitas Andalas. Padang, (2002).

4. A. Trisanti, Produksi dan tekno ekonomi amilase untuk menunjang industri dalam negeri, Dikti 2009.

5. R. Trifani, Amobilisasi enzim amilase dari ubi jalar pada matrik perlit yang telah diaktivasi, Universitas Andalas, Padang, (2002).

6. A. Laila dan J. Hendri, Studi pemanfaatan polimer kitin sebagai media pendukung amobilisasi enzim amylase, Universitas Lampung, Lampung, (2008).
7. M. Ham, Membuat reagen kimia di laboratorium, Penerbit PT Bumi Aksara, Jakarta, (2008).

8. R. Noorma, Pengaruh perbedaan metode aktivasi terhadap efektifitas zeolit sebagai adsorben, Majalah farmasi Airlangga., 4(1): 20, (2004).

9. H. Liesbetini, Immobilisasi enzim, M. K enzim. IPB, (2008).

10. A. Budiman dan S. Setyawan, Pengaruh konsentrasi substrat, lama inkubasi dan $\mathrm{pH}$ dalam proses isolasi enzim xylanase dengan menggunakan media jerami padi, Universitas Diponegoro, Sema-rang.

11. Charlena, Pencirian dan uji aktivitas katalitik zeolit alam teraktivasi, Jurnal riset kimia., 1(2): 107 - 115, (2008).

12. G. Mutngimaturrohmah dan Khabibi, Aplikasi zeolit alam terdealuminasi dan termodifikasi HDTMA sebagai adsorben fenol, Universitas Diponegoro, Semarang,

13. D. Srihapsari, Penggunaan zeolit alam yang telah diaktivasi dengan larutan $\mathrm{HCl}$ untuk menjerap logam-logam penyebab kesadahan air, Universitas Negeri Semarang, Semarang, (2006).

14. A. Fatha, Pemanfaatan zeolit aktif untuk menurunkan bod dan cod limbah tahu, Universitas Negeri Semarang. Semarang, (2007).

15. S. Sho, S. Takata, Haruo, Taguchi, and Noboru Yoshimura, Development of novel carrier using natural zeolite and continous ethanol fermentation with immobilized saccharomyces cerevisiae in a bioreactor, Biotecnology Letters., 23, (2001)

16. O. Banu, Immobilization of lipase from candida rugosa on hydrophobic and hydrophilic supports, Ýzmir Institute of Technology, Turki, (2001)

17. A. Setiawan dan T. Wibisono, Produksi enzym $\alpha$-amylase dari Bacillus subtilis. ITS, Surabaya, (2006).

18. C. Rocha, M. P. Gonçalves, and J. A. Teixeira. 2003. Trypsin immobilisation on zeolites, Portugal

19. R. Bakri, T. Utari, dan I. P. Sari, Kaolin sebagai sumber $\mathrm{SiO}_{2}$ untuk pembuatan katalis $\mathrm{Ni} / \mathrm{SiO}_{2}$ karakterisasi dan uji katalis pada hidrogenasi benzena menjadi sikloheksana, UI, Jakarta. 
20. K. Vidilaseris, Karakterisasi $\alpha$-amilase pendegradasi pati mentah bakteri laut bacillus subtilis alshl3, ITB, Bandung, (2007).
21. F. G. Winarno, Kimia pangan dan gizi, Jakarta: Penerbit PT. Gramedia Pustaka Utama, (1997) 